\title{
Crop adaptation to climate change in the semi-arid zone in Tanzania: the role of genetic resources and seed systems
}

\author{
Ola T Westengen ${ }^{1,2^{*}}$ and Anne K Brysting ${ }^{2}$
}

\begin{abstract}
Background: Rural livelihoods relying on agriculture are particularly vulnerable to climate change. Climate models project increasingly negative effects on maize and sorghum production in sub-Saharan Africa. We present a case study of the role of genetic resources and seed systems in adapting to climatic stress from the semi-arid agroecological zone in Tanzania.

Results: Crop adaptation, switching to more drought-tolerant crop species or varieties, is an important adaptation strategy within a diverse portfolio of livelihood responses to climatic stress. Crop adaptation involves the adoption of improved maize varieties combined with continued use of local varieties of both maize and sorghum. Regression modelling shows that households receiving the extension service and owning livestock are more likely to switch to drought-tolerant varieties as a response to climatic stress than those without access to these assets. The seed system in the study area consists of both formal and informal elements. The informal channels supply the highest quantities of both sorghum and maize seeds. Recycling of improved varieties of maize is common and the majority of households practice seed selection. Detailed assessment of the three different categories of genetic resources - local, improved and farmer-recycled varieties - reveals that drought tolerance is more frequently reported as a reason for growing local varieties than for growing improved varieties of maize and sorghum. The significantly later maturity reported for local varieties compared to the improved varieties bred to have a short growing cycle indicates that households distinguish between drought-tolerance and drought-avoidance traits.

Conclusions: Seed system perspectives on crop adaptation offer insights into the complex ways crop adaptation is realized at the livelihood level. The integration of informal and formal seed system elements is important for the adaptive capacity of agriculture-based livelihoods. Our findings highlight the value and importance of location-specific information about crop variety use for arriving at realistic recommendations in impact and adaptation studies.
\end{abstract}

Keywords: Adaptation, Agriculture, Seed systems, Genetic resources, Maize, Sorghum

\section{Background}

Adaptation to climate change is a major issue in the current food security discourse [1,2]. Livelihoods in developing countries depending on agriculture are particularly vulnerable to changes in the mean and variability of climate and the need for adaptation is highlighted in crop impact studies from sub-Saharan Africa (SSA) [3,4]. Adaptation options in agriculture involve changes at the farm management level as

\footnotetext{
* Correspondence: ola.westengen@sum.uio.no

${ }^{1}$ Centre for Development and the Environment, University of Oslo, Blindern,

P.O. Box 1116, NO-0317 Oslo, Norway

${ }^{2}$ Centre for Ecological and Evolutionary Synthesis (CEES), Department of

Biosciences, University of Oslo, Blindern, P.O. Box 1066, NO-0316 Oslo, Norway
}

well as changes in the policy and institutional decision environment [5]. In the portfolio of common on-farm and non-farm livelihood adaptation strategies, crop adaptation (changing to crop species or varieties that are resistant to climatic stress) is among the most cited adaptation measures [3-10]. The important role that crop adaptation has achieved in the discourse is illustrated by a United Nations General Assembly resolution from 2009, which 'underlines the importance of ... making crops more tolerant to environmental stress, including drought and climate change' [11]. Despite the general agreement about the importance of crop adaptation there are diverging views in the adaptation literature 
about how this adaptation option can be realized at the livelihood level.

The need to adapt crops to changing environmental conditions is not new, rather it is the most fundamental coevolutionary relationship between crops and humans since the dawn of agriculture [12,13]. Crop adaptation in the Darwinian sense is the evolution of crops to become better suited to their environments. In traditional agriculture, adaptation is an interplay between natural selection and selection by farmers. In modernized agriculture, which has been rapidly spreading in the developing world with the Green Revolution since the 1960s, the science of plant breeding has largely replaced the farmer's role in crop development [14]. Conventional plant breeding can briefly be defined as crossing plants with desired characteristics and selecting offspring combining those desirable characteristics to produce so-called improved varieties. The technology and the political economic context are different, but genetic diversity is the raw material for adaptation both in on-farm crop development and in professional plant breeding. This role of crop diversity is reflected in the term genetic resources, which encompasses seeds, plants and plant parts useful in crop breeding, research or conservation for their genetic attributes [15]. In traditional agriculture, genetic resources for adaptation are sourced from the farmer's own field or through gifts and trade with other farmers, and sometimes through gene flow from other varieties or wild relatives of the crop. In modernized agriculture, the plant breeders act as intermediaries between the genetic resources and the farmer, and the genetic resources used to breed new varieties are normally sourced from genebanks and genetic stocks.

The terms informal and formal seed systems are used to distinguish between the two different sources of genetic resources [16,17]. In SSA's smallholder agriculture, most seeds are sourced through the informal seed system and only a small proportion of the seeds planted every year are sourced through formal market channels with direct links to plant breeding $[18,19]$. However, farm saving and recycling of improved varieties is common [20-22]. Socioeconomic work from Mexico has demonstrated that recycling and hybridization between landraces and improved varieties of maize is a deliberate strategy used by smallholder farmers to combine desirable traits from improved and local varieties, a phenomenon known as creolization $[23,24]$. Thus, the distinction between the formal and informal seed systems is not clear-cut. Development initiatives aiming at replacing the informal seed system with formal seed systems modelled after those found in industrialized countries have been questioned and challenged in recent seed system literature [25-28].

Vermeulen et al. [8], in a review of options to support agriculture and food security under climate change, point out that while we know much about what regions and crops are likely to be sensitive to climate change, there is limited scientific knowledge about how current farming systems can adapt. This gap arguably reflects methodological and epistemological differences between two scholarly traditions dealing with agriculture in a climate change context. The first is impact oriented and the other studies the vulnerability and capacity of affected livelihoods $[29,30]$. While there is no clear-cut boundary between the two literatures, their difference is apparent in the Intergovernmental Panel on Climate Change (IPCC) report from Working Group II on Impacts, Adaptation and Vulnerability [31] where the two literatures are reviewed by different expert groups in different chapters [6,32]. The impact-oriented literature projects yield loss in the largest food crops and focuses on the consequences for regional and national food security, often with a view to recommending targeting of adaptation measures $[3,6,33,34]$. The literature on capacity and vulnerability commonly applies a livelihood and poverty perspective on adaptation [32,35,36] and typically treats coping and adaptation as objects for empirical research. The difference in starting point (crop impact vs socio-economic impact) often leads to differences in recommendations with regard to how crop adaptation can be realized in developing countries. The impact-oriented literature projects shifts in crop climates that are likely to make the current crop varieties unsuitable and commonly arrives at recommending breeding and dissemination of stress-tolerant and climate-ready varieties. On the other hand, the focus on local conditions and safety nets in the vulnerability and capacity studies often leads to an emphasis on the adaptive importance of local crops and traditional knowledge.

We here present a study of crop adaptation in an area where households experience climate stress and cultivate crops for which climate change models project adverse effects on future yield. This paper is a contribution towards bridging the gap between different scholarly traditions on climate change adaptation. We apply a combination of the livelihood approach and seed system perspectives when addressing the following research questions: (a) Is crop adaptation an important adaptation strategy? (b) What livelihood factors are associated with practicing on-farm adaptation activities in general and crop adaptation in particular? (c) What is the role of genetic resources and seed systems in crop adaptation?

\section{Methods}

\section{Study site and impact projections}

The current study was carried out during the harvest season in 2010 in two Tanzanian villages: Mangae in the Morogoro district and Laikala in the Dodoma district (Figure 1). The agricultural sector is the main source of employment and livelihood for $77.5 \%$ of the population in Tanzania [37]. Despite food self-sufficiency at the national 


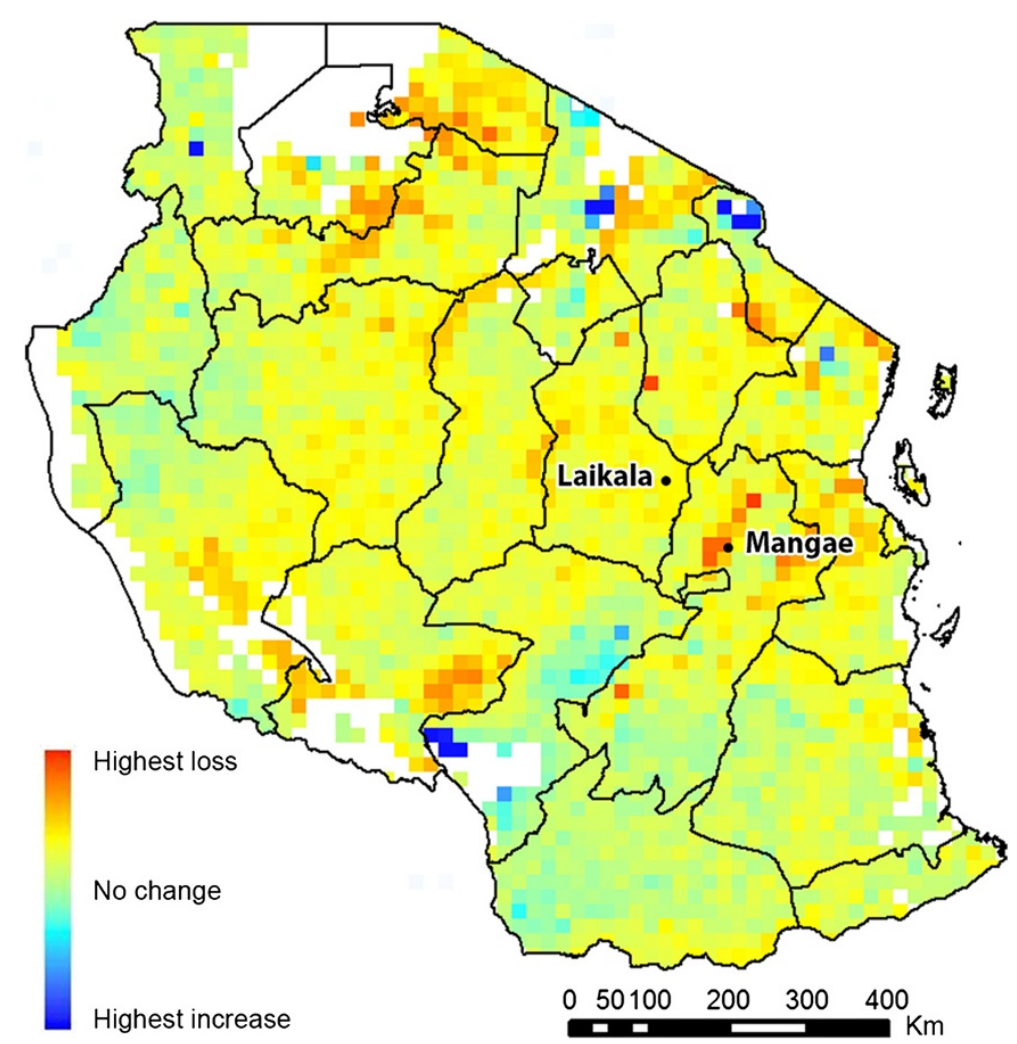

Figure 1 Map of study sites and maize production impacts. Tanzania and the villages Mangae in the Morogoro district and Laikala in the Dodoma district. Simulated change in percentage of maize yield in 2050 compared to current conditions in 10 arc-minute grids based on the mean value from the CERES-Maize model run on downscaled data from two GCMs and two SRES scenarios (HadCM3 and ECHam 4 models, A1 and B1 scenarios). Map based on data from Thornton et al. [4].

level, one third of the population is unable to meet their dietary energy requirements [38]. Maize is the largest crop, produced on $58 \%$ of the total cereal area in 2010, and sorghum is the third most produced crop nationally after maize and rice [39]. We used three criteria to select study sites: (1) the sites are located in areas with projected negative effects of climate change on maize and sorghum production, (2) agriculture is today climatically stressed and (3) maize and sorghum are major crops in the agricultural part of people's livelihood.

Impact projections for maize and sorghum yields vary according to the scale and model used. At the regional SSA scale, Schlenker and Lobell [40] coupled historical crop production data with predictions for temperature and precipitation changes from 16 climate change models under the A1b emission scenario of the IPCC, and projected aggregate production losses of $17 \%$ for sorghum and $22 \%$ for maize by mid-century. For Tanzania, the nationally projected impact of a $2^{\circ} \mathrm{C}$ seasonal temperature increase is an $8.8 \%$ reduction of sorghum yield and $13 \%$ for maize in the same period [41]. Thornton et al. [4] ran the biophysical crop model CERES-Maize [42] with a fine spatial resolution (10 arc-minute grids or $\sim 18 \mathrm{~km}$ resolution) across East Africa, and predicted that the semiarid region in Tanzania is one of the areas where maize yields are likely to be reduced by $20 \%$ or more. The villages in the current study are located in areas where maize production is predicted to be adversely affected (Figure 1).

\section{Theoretical framework and statistical methods}

We used a livelihood approach $[43,44]$ to study adaptation and assess the relative importance of crop adaptation in light of the institutional context and other adaptation options accessible to the households. Drawing on the seed system literature $[17,25,27]$, we study seed systems as the institutions that mediate access to genetic resources. Furthermore, we analyze the association between different categories of genetic resources and a range of production and consumption variables, drawing on the socio-economic literature on the benefits of different types of crop varieties $[24,45]$.

We used both qualitative and quantitative methods when collecting and analyzing the data. We conducted key informant interviews of actors in the formal seed system in the area of research as well as with villagers and authorities in the villages included in our case study. The quantitative 
analysis is based on a random sample of 320 households in two villages, who were interviewed using a structured questionnaire with both closed and open-ended questions. The questionnaire consisted of four sections: a section on asset status, a section on stress factor ranking, a section on coping activities in times of stress and a section on the seed system and varieties used. In the section on coping activities we asked if households were practicing any of the activities on a list of coping activities and if the reason was climatic stress or other stressors. The list was based on coping activities documented in the literature $[22,46,47]$ and elicited in the initial qualitative phase of data collection. We used logistic regression models with the common on-farm coping activities (practiced by more than 15\% of the households due to climatic stress) as response variables and a set of livelihood factors as explanatory variables. In these models the log odds of the activities were modeled as a linear combination of the explanatory variables. The explanatory variables included in our model were chosen based on hypotheses of either positive or negative associations with the response variables based on findings in other quantitative adaptation studies $[10,48,49]$. To account for asset status we included human capital variables (household size and the sex, age and education of the household head), financial capital variables (annual income and a dummy variable for livestock ownership), an institutional dummy variable on the extension service on cropping and a village effect dummy variable. The modeling was coded in $\mathrm{R}$ [50] and the models were evaluated with a Wald test from the Analysis of Overdispersed Data package [51].

The seed system part of the survey was formulated first by asking about sources of seeds and planting material for all crop species cultivated and second by asking in detail about area allocation and quality aspects of the different varieties of maize and sorghum. First, we classified the different seed sources as either formal or informal based on the seed system typology outlined in Sperling et al. [17]. Second, we classified the different varieties as belonging to one of the three genetic resource categories: local, improved or farmer-recycled. The classification was based on information provided by the household on the variety cultivated and cross-checked with information on variety names and history from key informant interviews with farmer groups, extension workers and plant breeders. The term 'local varieties' is used to distinguish the varieties said to have a long history in the area from the improved varieties produced in the formal seed system. For sorghum we could have used other terms such as 'landrace' or 'traditional variety', but in the outcrossing crop maize, which is subject to gene flow from recently introduced varieties, these terms are problematic and we chose to use the same terminology for both crops. Farm-saved improved varieties re-used on a farm in two seasons or more were classified as farmer-recycled. We tested the correlation between crop switching and the area cultivated to the different categories using the non-parametric correlation test Spearman's rho $(\rho)$. Finally, we analyzed the deviance between local and improved varieties with regard to a range of production and consumption variables using a chi-square test.

\section{Results and discussion}

\section{Livelihoods under stress}

The households ranked drought, conflict or competition over water and the unreliable onset of the rainy season as the three worst stress factors (Figure 2). Thus, problems of availability and access to water and seasonal variability are considered worse than biotic stress caused by crop diseases, destruction of fields by wild animals, problems with market access or floods caused by excessive rains. Other studies from the area have similarly found that climatic stress is the major factor behind the reduction in agricultural productivity and that the perception that there is a need to adjust livelihoods to an increased risk for drought and changes in rainfall and temperature is common in the semi-arid zone in Tanzania [52,53].

The livelihood approach is a lens for studying complex rural development questions and is widely used to study risk responses in rural livelihoods [43,44]. Ellis [43] defines a livelihood as: 'the assets, the activities and the access to these that together determine the living gained by the individual or household'. Households in Laikala and Mangae practice a wide range of coping activities and climatic stress is a major cause behind the diverse livelihood strategy portfolio (Figure 3). We found that receiving food aid is the most common way to cope with climatic stress among all activities recorded. The other three non-farm climatic stress responses undertaken by more than $15 \%$ of the households are: cutting back on the number of meals per day, incurring debt and using informal community support networks. Assessments of climatic stress responses of smallholders in developing countries often find the distinction between coping and adaptation to be blurred [54-56]. The common non-farm responses recorded in this study are short-term measures used to cope with stress while most of the on-farm strategies fit well with the IPCC definition of adaptation: 'the process of adjustment to actual or expected climate and its effects, in order to moderate harm or exploit beneficial opportunities' [31]. Seven on-farm activities are practiced by more than $15 \%$ of the villagers: shifting the cropping area, switching to drought-tolerant varieties, shifting planting dates, switching to droughttolerant species, diversifying crops, extending farmland and diversifying livestock. These activities involve forward planning to anticipate climatic stress and are not merely ways to cope and survive during unexpected stress events. The diversity of livelihood activities is typical for rural households facing climatic stress in the region [47,52,57-60] and the importance of on-farm strategies recorded here 


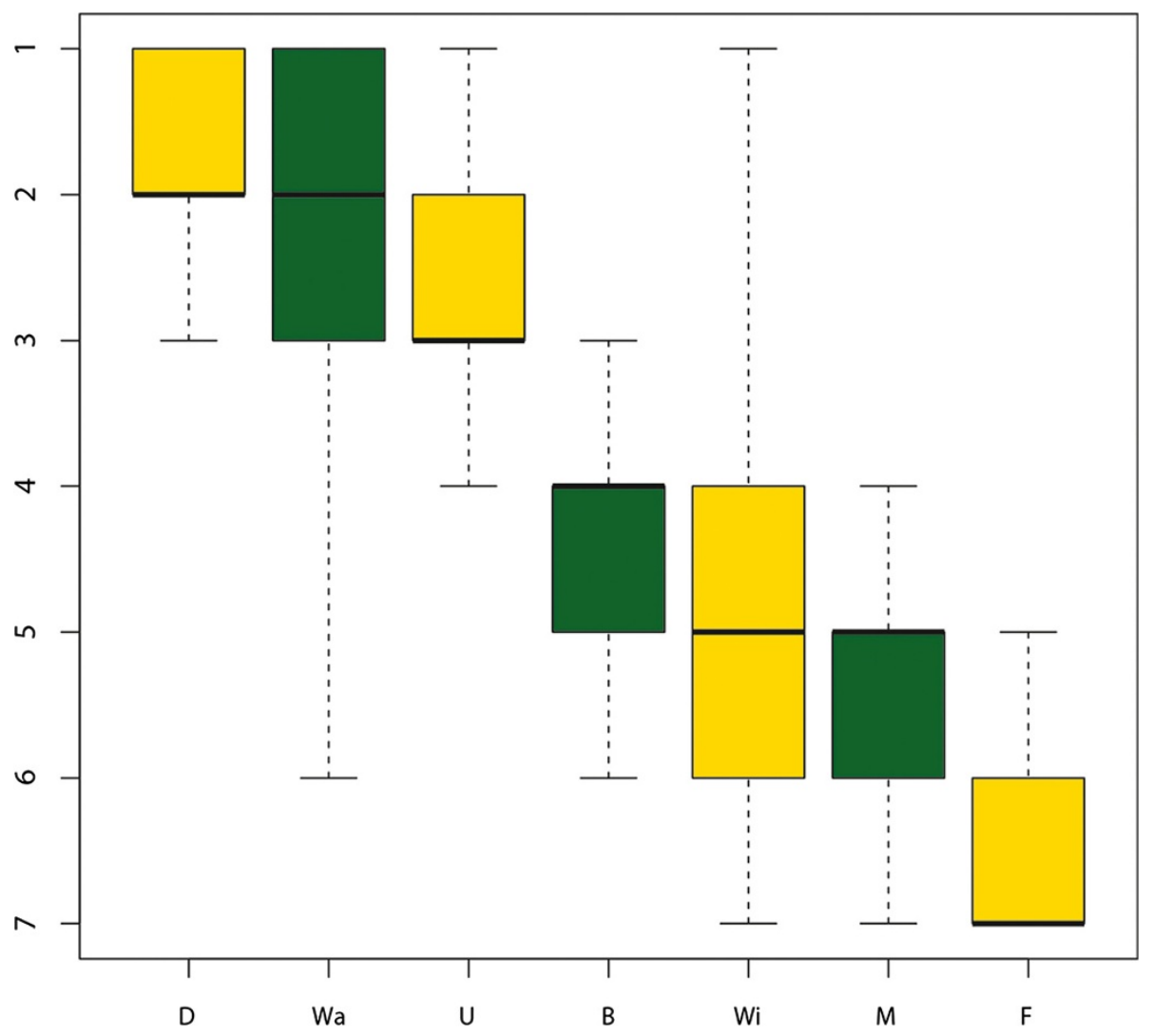

Figure 2 Stress factors ranked by households. Box plot with mean (bold line), quartiles (boxes) and variability outside the upper and lower quartiles (whiskers). Stress factors ranked from 1 (worst) to 7 by households in Mangae and Laikala ( $n=320)$ : drought (D); conflict or competition over water (Wa); unreliable onset of the rainy season (U); biotic stress (B); wild animals (Wi); market access (M); floods (F).

resonates with findings in other studies of rural livelihood strategies in Morogoro and Dodoma [46,58,59]. In this livelihood framing of crop adaptation we find that the two crop adaptation activities assessed are among the most important responses to climatic stress, with $46 \%$ and $40 \%$ of all respondents having switched to drought-tolerant varieties and drought-tolerant crop species, respectively. Thus, crop adaptation is a central part of the livelihood response to climatic stress in the area.

\section{Determinants of adaptation}

To determine what livelihood factors are associated with undertaking on-farm adaptation activities in general and crop adaptation in particular we modelled the seven most important on-farm activities as a linear combination of a set of explanatory variables representing household asset status. The explanatory variables included in our models have a joint significance in six of the adaptation activity models tested (Table 1). The only model for which the selected variables were not jointly significant was the activity 'shift planting dates' $(P=0.12)$. Only two explanatory variables representing asset status are significantly correlated with crop adaptation, namely livestock ownership and receiving the extension service. Both switching to droughttolerant varieties and switching to drought-tolerant species are positively correlated with livestock ownership, indicating that livestock owners are more likely to practice crop adaptation than those without livestock. Receiving the extension service has a significant positive effect on switching to drought-tolerant varieties and extending farmland. There is a significant village effect with households in Laikala, the driest village, being less likely to switch to drought-tolerant varieties and more likely to switch to drought-tolerant species than those in Mangae.

Before further discussion of the livelihood factors associated with crop adaptation, it is useful to consider what kind of genetic resources are used by the respondents who answered that they had switched to a drought-tolerant variety as a response to climatic stress. While the intention was to capture all kinds of variety switches, it appears that for maize the respondents understood the question as whether they have switched to an improved drought-tolerant variety. Two findings support this conclusion: (1) the significant positive association with households receiving the extension service in the regression model and (2) the significant positive correlation between this activity and the area allocated 


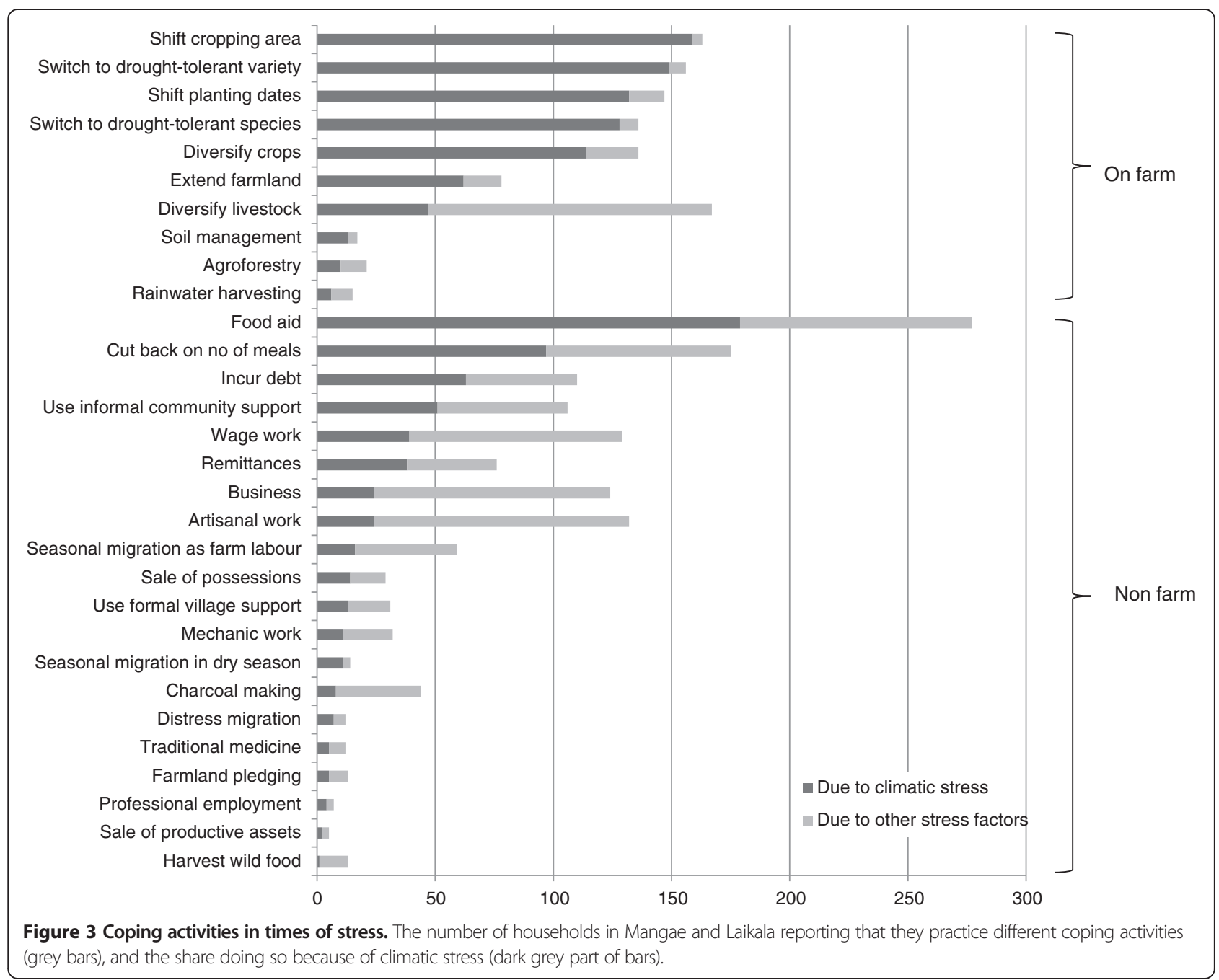

Table 1 Regression models for on-farm coping activities practiced by households with livelihood factors as explanatory variables $^{\mathrm{a}}$

\begin{tabular}{|c|c|c|c|c|c|c|}
\hline Activity & $\begin{array}{c}\text { Shift } \\
\text { cropping area }\end{array}$ & $\begin{array}{c}\text { Switch to } \\
\text { drought-tolerant } \\
\text { variety }\end{array}$ & $\begin{array}{c}\text { Switch to } \\
\text { drought-tolerant } \\
\text { species }\end{array}$ & $\begin{array}{l}\text { Diversify } \\
\text { crops }\end{array}$ & $\begin{array}{l}\text { Extend } \\
\text { farmland }\end{array}$ & $\begin{array}{l}\text { Diversify } \\
\text { livestock }\end{array}$ \\
\hline Sex of household head & $8.145 \times 10^{-1 * *}$ & $-3.489 \times 10^{-2}$ & $-9.470 \times 10^{-2}$ & $-4.035 \times 10^{-1}$ & $6.545 \times 10^{-1 *}$ & $9.329 \times 10^{-1 * *}$ \\
\hline Age of household head & $-6.419 \times 10^{-3}$ & $-2.961 \times 10^{-3}$ & $-1.244 \times 10^{-3}$ & $-8.348 \times 10^{-3}$ & $-6.811 \times 10^{-3}$ & $-2.073 \times 10^{-3}$ \\
\hline Education & $4.804 \times 10^{-1}$ & $-2.739 \times 10^{-1}$ & $1.001 \times 10^{-1}$ & $-1.753 \times 10^{-1}$ & $9.645 \times 10^{-2}$ & $-9.479 \times 10^{-2}$ \\
\hline Household size & $1.203 \times 10^{-2}$ & $-9.705 \times 10^{-3}$ & $4.775 \times 10^{-2}$ & $2.682 \times 10^{-2}$ & $-1.095 \times 10^{-2}$ & $1.589 \times 10^{-1 * *}$ \\
\hline Livestock ownership & $9.324 \times 10^{-1 *}$ & $7.656 \times 10^{-1 *}$ & $1.037^{* *}$ & $1.069 \times 10^{-1}$ & $2.780 \times 10^{-1}$ & $2.520 * * *$ \\
\hline Annual income & $-2.906 \times 10^{-8}$ & $1.925 \times 10^{-8}$ & $8.799 \times 10^{-11}$ & $5.494 \times 10^{-8}$ & $7.887 \times 10^{-8}$ & $7.698 \times 10^{-8}$ \\
\hline Extension service & $2.388 \times 10^{-3}$ & $8.177 \times 10^{-1 * *}$ & $2.184 \times 10^{-1}$ & $8.109 \times 10^{-2}$ & $6.252 \times 10^{-1 *}$ & $-1.855 \times 10^{-1}$ \\
\hline Village effect & $7.638 \times 10^{-1 * *}$ & $-6.596 \times 10^{-1 *}$ & $8.010 \times 10^{-1 * *}$ & $5.785 \times 10^{-1 *}$ & $2.861 \times 10^{-2}$ & $9.071 \times 10^{-1 * *}$ \\
\hline Wald test & $P=0.00017$ & $P=0.011$ & $P=8.8 \times 10^{-5}$ & $P=0.017$ & $P=1.7 \times 10^{-13}$ & $P=1.8 \times 10^{-7}$ \\
\hline
\end{tabular}

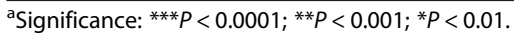


to improved varieties $(\rho=0.19, P<0.001)$. In comparison, the area allocated to local varieties is negatively correlated with the same activity $(\rho=-0.17, P<0.01)$. Thus, rather than capturing all kinds of adaptive switches, the question apparently mainly captures the adoption of improved varieties.

In this study we did not find the typical human capital factors usually associated with adoption of improved varieties, such as household size and the sex, education and age of the household head [61], to be significantly positively associated with crop adaptation. Out of the two financial capital variables included, annual income and possession of livestock, only the latter positively affected the probability of undertaking crop adaptation. Interestingly, the same pattern was found for wealth indicators in a scoping study for drought-tolerant maize done by the International Maize and Wheat Improvement Centre (CIMMYT) in East Africa [62]. The same study found that neither the length of education nor the sex of the household head affected the purchasing of improved varieties in Tanzania, while these factors significantly enhanced the likelihood in other countries in SSA. A study from Ethiopia [10] found that larger households headed by older males with more education and higher income were more likely to undertake crop adaptation. A study from Malawi [63] similarly found that larger households headed by males and experiencing climate-related shock were more likely to purchase seeds. The lack of positive association between the household's human capital and crop adaptation in this study indicates that institutional factors play a larger role. This is confirmed by the positive association between receiving the agricultural extension service and switching to drought-tolerant varieties. The government's extension service is promoting improved varieties of both sorghum and maize in the villages studied and some of the varieties are promoted as drought-tolerant. Prior to the growing season, during which this study was undertaken, improved maize varieties were sold through the extension service at subsidized rates in Mangae and improved sorghum was distributed by the extension service in Laikala under a seed aid program. The subsidized and free distribution of improved varieties is supposed to target the poorest and most needy households. This probably explains why receiving the extension service seems to 'trump' other factors that normally influence the likelihood of cultivating improved seeds. The important role of participation in government programs is observed in several studies of determinants of adoption of improved varieties from other areas $[45,64]$.

\section{The role of the seed system}

The local seed system consists of both formal and informal elements and the largest proportion of seeds is sourced through informal seed channels both for maize and sorghum (Table 2). Among the four informal seed sources most seeds are sourced from farmers' own harvest for both crops and the local seed market is the second most important channel. For maize, $24 \%$ of seeds are sourced through seed sources classified as formal seed system channels, while in sorghum only $8 \%$ are from these channels. In the terminology of the livelihood approach, seeds are important assets for agriculture-based livelihoods and seed systems embody the institutions that mediate access to this asset. This assessment thus demonstrates that the informal seed system is more important than the formal system, measured in the quantity of seeds accessed, but also the formal system provides a considerable quantity of maize seeds in the study area.

Distinguishing between the three genetic resource categories (local, improved and farmer-recycled varieties), we see a marked difference between maize and sorghum (Figure 4). For sorghum, local varieties dominate both in terms of the number of households cultivating them and in terms of the area allocated. For maize, improved varieties are somewhat more commonly cultivated than local varieties and farm saving and recycling of seeds is quite common. A relatively limited number of households cultivates two or three categories of maize, but most cultivators of improved sorghum also cultivate local varieties. The dominance of the informal seed system for maize outlined in the previous section is thus not coupled with a similar dominance of local varieties. The informal maize seed system is open to an influx of improved varieties originating in the formal seed system. Farmers' seed use is more complex than a mere choice between different varieties off-the-shelf from the informal or the formal seed system. A large proportion of the respondents reported that they select seeds for next year's planting. Out of the 275 sorghum-growing households in our survey, $77 \%$ practice selection and among the 310 maize-growing households, $78 \%$ practice selection. The combination of recycling of improved open-pollinated maize varieties and seed selection suggests that improved varieties

Table 2 Proportion of maize and sorghum seeds sourced from different supply channels in Mangae and Laikala

\begin{tabular}{|c|c|c|c|c|c|c|c|c|c|}
\hline \multirow[t]{2}{*}{ Crop } & \multicolumn{7}{|c|}{ Seed source (percentage) ${ }^{a}$} & \multirow{2}{*}{$\begin{array}{c}\text { Formal } \\
\text { (percentage) }\end{array}$} & \multirow{2}{*}{$\begin{array}{c}\text { Informal } \\
\text { (percentage) }\end{array}$} \\
\hline & Own & Barter & Gift & Local market & Shop & Government & Other & & \\
\hline Maize & 42 & 6 & 4 & 21 & 9 & 15 & 3 & 24 & 73 \\
\hline Sorghum & 61 & 9 & 7 & 11 & 5 & 3 & 5 & 8 & 87 \\
\hline
\end{tabular}

${ }^{a}$ Seed source share is given as percentage of total weight of seeds reported for the crop. Seeds from own harvest, through barter, gift and local market are classified as informal seed channels. Seeds from shop and government provision are classified as formal channels. 


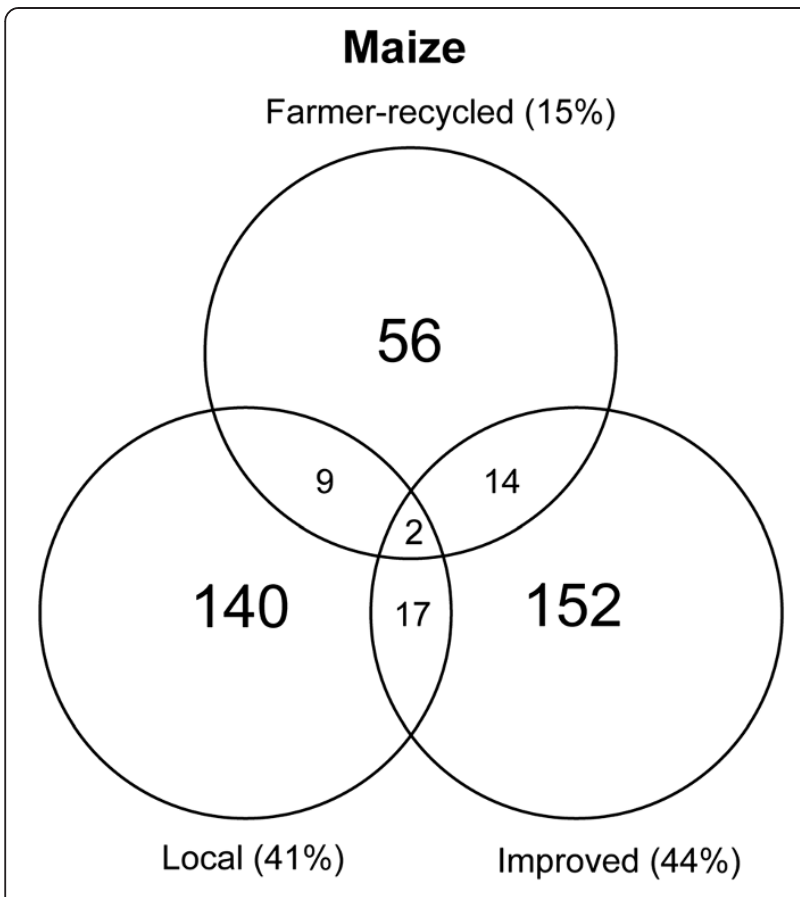

Sorghum

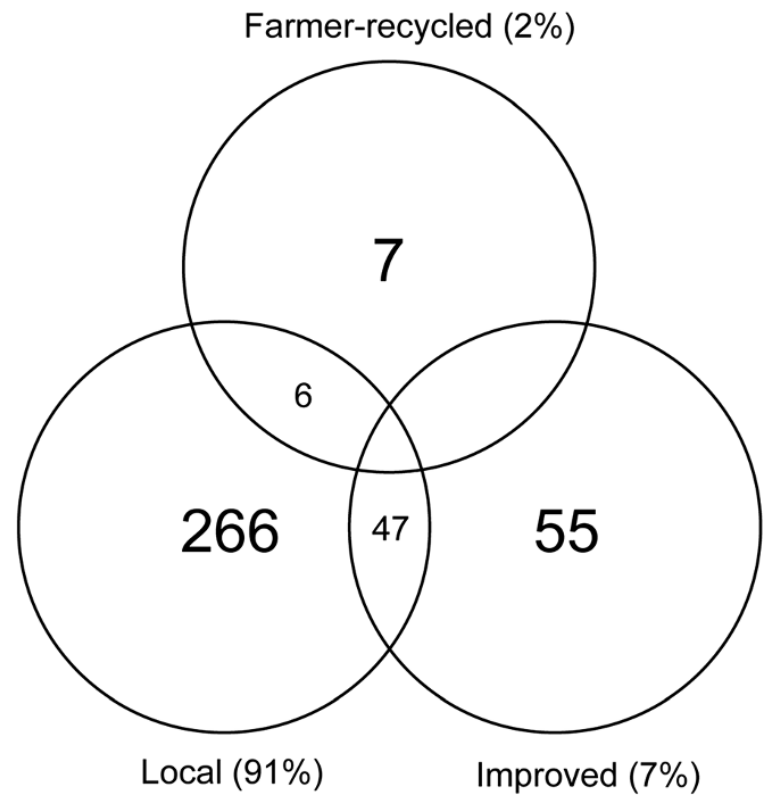

Figure 4 Maize and sorghum cultivation. Venn diagram showing the number of households in Mangae and Laikala cultivating one or more of the three genetic resource categories of maize and sorghum (see text for definitions of categories). The numbers of households are absolute for every category and every combination of categories. The percentage of the cultivated area allocated to each of the three categories is given in brackets outside the circles.

are used as genetic resources with beneficial creolization as a potential outcome. In another paper we explore the consequences of this seed management in more depth using single nucleotide polymorphisms to study genetic diversity and differentiation in the local maize seed system in one of the villages in this study [65].

The assessment of households' reasons for cultivating the different genetic resource categories and their perceptions of consumption and production qualities casts more light on the complexity of crop adaptation (Table 3). The average field size allocated to local varieties compared to the size of fields planted with improved varieties is significantly larger both for maize and sorghum, but the difference is more marked for sorghum. Drought tolerance is the most frequently reported reason for growing both maize and sorghum. We found that $57 \%$ of the local maize cultivators and $81 \%$ of the local sorghum cultivators reported drought tolerance as a major reason for cultivating the local varieties. Yield receives the second highest score among the cultivators of local varieties of both crops and is the most reported reason for cultivating improved maize. Biotic stress resistance receives a low to zero score as a major reason for cultivation across all genetic resource categories. This is in line with the results of the stress factor ranking and confirms that abiotic stress is perceived as a more serious problem than biotic stress by households in this area. The higher proportion of households reporting drought tolerance as a reason for cultivating local sorghum than for cultivating local maize reflects that sorghum is a considerably more drought-tolerant crop species than maize [18]. The shift to improved varieties due to climatic stress indicated by the regression model is not reflected in the assessment of production variables. On the contrary, a significantly higher proportion of households report cultivating local varieties of both crops because of their drought tolerance compared to those reporting cultivation of improved varieties for this reason. Among the two consumption variables assessed, tastiness and storability, we did not find significant differences between improved and local varieties.

The scores given by households to the two production variables, maturity and drought resistance, reveal a complexity in the perception of traits relevant for withstanding climatic stress. Local varieties of both sorghum and maize are reported to have a significantly longer maturity period than improved ones. Since a short time for maturation is generally considered a valuable droughtresistance trait $[62,66]$, this is apparently contradictory to the finding of no significant difference between the average household scores given to local and improved varieties for this trait. A possible explanation can be found in the scientific definition of drought resistance, which is commonly defined as encompassing both drought avoidance and drought tolerance. Varieties that do not avoid drought and need a long growing period to mature might still be relatively drought resistant because they are able to tolerate drought. 
Table 3 Production and consumption variables reported by households in Mangae and Laikala for each field ${ }^{\mathrm{a}}$

\begin{tabular}{|c|c|c|c|c|c|c|c|}
\hline \multirow{2}{*}{ Variable } & & \multicolumn{3}{|c|}{ Maize } & \multicolumn{3}{|c|}{ Sorghum } \\
\hline & & $\begin{array}{c}\text { Local } \\
(n=156)\end{array}$ & $\begin{array}{c}\text { Improved } \\
(n=189)\end{array}$ & $\begin{array}{l}\text { Farmer-recycled } \\
\qquad(n=60)\end{array}$ & $\begin{array}{c}\text { Local } \\
(n=290)\end{array}$ & $\begin{array}{c}\text { Improved } \\
(n=56)\end{array}$ & $\begin{array}{l}\text { Farmer-recycled } \\
(n=7)\end{array}$ \\
\hline Field size & Acres & $3.73^{*}$ & 3.27 & 3.36 & $3.28^{* * *}$ & 1.42 & 3.36 \\
\hline \multirow[t]{3}{*}{ Reason for growing ${ }^{b}$} & Drought tolerance & $0.57^{*}$ & 0.41 & 0.46 & $0.81^{*}$ & 0.57 & 0.57 \\
\hline & Yield & 0.52 & 0.53 & 0.71 & 0.35 & 0.33 & 0.57 \\
\hline & Biotic stress resistance & 0 & 0.01 & 0 & $0.01^{*}$ & 0 & 0 \\
\hline \multirow[t]{2}{*}{ Consumption } & Storability $^{c}$ & 1.26 & 1.24 & 1.22 & 1.56 & 1.22 & 1 \\
\hline & Tastiness ${ }^{c}$ & 1.02 & 1.08 & 1.07 & 1.11 & 1.13 & 1 \\
\hline \multirow[t]{2}{*}{ Production } & Maturity ${ }^{d}$ & $1.97^{* * *}$ & 1.31 & 1.34 & $2.90^{* * *}$ & 1.39 & 1.86 \\
\hline & Drought resistance ${ }^{e}$ & 1.94 & 1.96 & 1.77 & 1.37 & 1.57 & 1.57 \\
\hline
\end{tabular}

${ }^{a}$ The mean values for the variables are reported with chi-square tests for the difference between the local and improved categories. Significance: $* * *<0.0001$; ${ }^{* *} P<0.001 ;{ }^{*} P<0.01$; ${ }^{b}$ Multiple responses for households listing up to three factors ( 1 if a major reason, 0 if not); ${ }^{\mathrm{C}} 1=\mathrm{Good}, 2=\mathrm{Ok}, 3=\mathrm{Not}$ so good; ${ }^{\mathrm{d}} 1<100$ days, $2=100$ to $120,3>120 ;{ }^{e} 1=$ Very good, $2=$ Good, $3=$ Not good.

The local varieties of sorghum in the study area take 5 to 7 months to mature and the local varieties of maize take more than 3 months. The improved varieties of sorghum and maize have considerably shorter maturation periods: from 120 days down to only 90 days for the earliest maturing varieties of both crops. The maize variety kito, which has a short maturation period, was recommended by the extension service due to the late onset of rains in the growing season when this study was conducted. However, short maturation period varieties are not necessarily the most robust varieties if drought strikes before flowering and grain filling $[67,68]$. Because of the unpredictable rains early in the growing season, drought escaping varieties such as kito might actually be less drought resistant than other improved and local varieties. This can explain why varieties with other physiological traits that are important for withstanding drought are favored by the households in Mangae and Laikala. The most commonly improved maize varieties are staha and TMV1, which were released by the public Tanzania Agricultural Research Organization. Neither are short maturation period varieties according to CIMMYT, which classifies staha as a very late maturing variety and TMV1 as an intermediate to late maturing variety [68]. The observation that short maturation period not necessarily is a reason for choosing a variety to cope with abiotic stress has also been observed in other studies of farmers' perceptions. In a study from Chiapas, Mexico, Bellon and Taylor [69] observed that while a short growing period was perceived as a positive trait associated with improved maize varieties, resistance to drought was a positive trait only attributed to local varieties. In a later study from the same area, drought resistance was ranked as one of the more important traits and one that was given a significantly higher rank for local compared to improved varieties [24].

The complexity in the perception of drought resistance is also apparent for sorghum in the study area. The sorghum variety wahi is, like the maize kito, an example of an improved short maturation period variety promoted by the formal seed system with very limited adoption among farmers. A short maturation period is a breeding target for sorghum in SSA because the day-length sensitivity common in local varieties is considered a production constraint [18]. The day-length-sensitive local varieties shift from vegetative to reproductive growth when the days shorten to a critical period, regardless of the date of planting. This trait has mixed implications for coping with and adapting to climatic stress. Its primary function is to ensure that grain matures under dry conditions, which is important for avoiding grain rot, mold and other diseases [18]. Thus, daylength sensitivity is an adaptation to the temporal habitat of the local varieties, and together with local preferences in taste and end-product use, this adaptation probably goes a long way to explaining the low adoption of improved sorghum among smallholders in the region. However, daylength sensitivity makes local varieties vulnerable to shifts in the normal seasonality. The photoperiod stays the same even if the climate conditions change and this raises questions about the adaptive potential of the local genetic resources as well as about the ability of the seed system to deliver this adaptation in a timely manner. The spatial scope of informal seed systems in providing farmers with appropriate genetic resources to adapt is beginning to attract research informed by climate projections [70]. Our results suggest that the temporal scope of seed systems warrants more research in this context.

\section{Conclusions}

\section{Seed system perspectives and adaptation}

There is mounting evidence that agriculture in SSA will have to adapt to the adverse effects of climate change and much attention from development practitioners and scholars is directed towards the question of the means of adaptation. It is generally agreed that the genetic resources of important food crops are key assets for adaptation in 
rural households, but different research outlooks lead to different conclusions about what kind of genetic resources best allows farmers to adapt. In an agricultural modernization perspective, crop adaptation is commonly framed as a question of the public and commercial development of improved varieties, and farmers' crop adaptation options are framed as the adoption of new technology. This framing of crop adaptation does not represent the current reality in subsistence agriculture in SSA, where most of the seeds planted are uncertified and sourced through informal seed system channels.

Framing crop adaptation with a livelihood approach captures the complex resource access situation faced by rural households in the semi-arid zone in Tanzania. The results presented here confirm that climatic stress is already a major stress factor in the livelihoods of people living in the area and that crop adaptation is among the more important responses used by households. Crop adaptation involves adoption of improved maize varieties combined with continued use of local varieties of both maize and sorghum, which despite their late maturity are valued for their drought tolerance. The seed system in the study area consists of both formal and informal elements, but the informal elements are the most important supply channels. All genetic resource categories are subject to on-farm selection and hybridization, and farmer selection may lead to incremental on-farm crop adaptation. Our findings support the view that the integration of informal and formal seed system elements will be important for agriculturebased livelihoods in meeting the challenges ahead [25-27].

This study highlights two important methodological challenges in impact and adaptation studies. First, the use of generic variety data in modeling crop impact on a large geographical scale may be problematic because of the diversity between crop varieties with regard to drought avoidance and drought tolerance traits. Biophysical crop models often fail to capture that varieties sourced through informal seed channels dominate smallholder agriculture in SSA. No single variety can represent the diverse situations in a single village, let alone in studies making projections at the national or regional level. The second methodological challenge is relevant for the small, but growing body of regression model-based adaptation studies in which a 'switch to a drought-tolerant variety' is used as a response variable. People's understanding of what a drought-tolerant variety constitutes is likely to be influenced by national and international development actors' promotion of improved varieties under this banner. In this study households' perceptions of the characteristics of and reasons for growing the different genetic resource categories reveal that local and recycled varieties play a role in adaptation to drought stress that was left undetected in the regression modeling. The perceptions of the varieties observed here are not objective measurements, but they are nevertheless important in understanding actual decision-making by farmers [24]. Different attributes of the varieties influence the use and allocation of land to local, improved and farmer-recycled varieties. Our findings highlight the value and importance of location-specific information about crop variety use for arriving at realistic recommendations in impact and adaptation studies. Seed system perspectives of crop adaptation offer insights into the complex ways crop adaptation is realized at the livelihood level and can contribute to increase knowledge of how farming in SSA can and will adapt to a changing climate.

\section{Abbreviations}

CIMMYT: International Maize and Wheat Improvement Centre IPCC: Intergovernmental Panel on Climate Change; SSA: sub-Saharan Africa.

\section{Competing interests}

The authors declare that they have no competing interests.

\section{Authors' contributions}

OTW designed the study, analyzed the data and drafted the manuscript. Both authors contributed to and approved the final manuscript.

\section{Acknowledgements}

This work was supported through a grant from the University of Oslo. We are grateful to Jans Bobert and Khamaldin Mutabazi from the project Resilient Agro-landscapes to Climate Change in Tanzania for invaluable support and advice during the fieldwork. We thank Philip K Thornton for providing the yield projection data used in Figure 1. We acknowledge Sokoine University of Agriculture for granting the research permit. We are grateful for the key information and advice we obtained from academic staff at Sokoine University, as well as the many actors in the formal seed sector. Special thanks go to the late maize breeder Alfred Moshi, who provided key insights into breeding and the adoption of improved maize in the study area. Many thanks are also due to Philip Daninga and the excellent group of MSc students who assisted with the fieldwork. Finally we would like to express our gratitude to the people and leaders of Mangae and Laikala villages for their willingness to participate in this study. This manuscript was improved by critical and insightful comments from Trygve Berg, Desmond McNeill and two anonymous reviewers.

Received: 4 November 2013 Accepted: 17 January 2014 Published: 1 February 2014

\section{References}

1. HLPE: Food security and climate change. A report by the high level panel of experts on food security and nutrition of the Committee on World food Security. Rome: FAO; 2012

2. Godfray HCJ, Beddington JR, Crute IR, Haddad L, Lawrence D, Muir JF, Pretty J, Robinson S, Thomas SM, Toulmin C: Food security: the challenge of feeding 9 billion people. Science 2010, 327(5967):812-818.

3. Lobell DB, Burke MB, Tebaldi C, Mastrandrea MD, Falcon WP, Naylor RL: Prioritizing climate change adaptation needs for food security in 2030. Science 2008, 319(5863):607-610.

4. Thornton PK, Jones PG, Alagarswamy G, Andresen J: Spatial variation of crop yield response to climate change in East Africa. Glob Environ Change: Human Policy Dim 2009, 19(1):54-65.

5. Howden SM, Soussana JF, Tubiello FN, Chhetri N, Dunlop M, Meinke H: Adapting agriculture to climate change. Proc Natl Acad Sci USA 2007, 104(50):19691-19696.

6. Easterling W, Aggarwal P, Batima P, Brander K, Erda L, Howden M, Kirilenko A, Morton J, Soussana J, Schmidhuber J: Food, fibre, and forest products. In Climate Change 2007: climate change impacts, adaptation and vulnerability, contribution of working group II to the fourth assessment report of the Intergovernmental Panel on Climate Change. Edited by Parry ML, Canziani OF, Palutikof JP, van der Linden PJ, Hanson CE. Cambridge, UK: Cambridge University Press; 2007:273-313.

7. Mclntyre BD, Herren HR, Wakhungu J, Watson RT: Agriculture at a crossroads. International Assessment of Agricultural Knowledge, Science and Technology for Development (IAASTD): Global report. Washington, DC, USA: Island Press; 2009. 
8. Vermeulen SJ, Aggarwal P, Ainslie A, Angelone C, Campbell BM, Challinor A, Hansen JW, Ingram J, Jarvis A, Kristjanson P: Options for support to agriculture and food security under climate change. Environ Sci Pol 2012, 15(1):136-144.

9. Bryan E, Deressa TT, Gbetibouo GA, Ringler C: Adaptation to climate change in Ethiopia and South Africa: options and constraints. Environ Sci Po/ 2009, 12(4):413-426.

10. Deressa TT, Hassan RM, Ringler C, Alemu T, Yesuf M: Determinants of farmers' choice of adaptation methods to climate change in the Nile Basin of Ethiopia. Glob Environ Change: Human Policy Dim 2009, 19(2):248-255.

11. United Nations general assembly resolution a/RES/64/197. [http://www.un.org/ en/ga/64/resolutions.shtml]

12. Darwin C: The variation of animals and plants under domestication. Middlesex, UK: The Echo Library; 2007.

13. Harlan JR: Crops and man. Madison, WI, USA: American Society of Agronomy; 1975

14. Murphy DJ: People plants and genes: the story of crops and humanity. Oxford, UK: Oxford University Press; 2007.

15. Fowler $\mathrm{C}$, Hodgkin T: Plant genetic resources for food and agriculture: assessing global availability. Annu Rev Environ Resour 2004, 29:143-179.

16. Almekinders CJM, Louwaars NP, Debruijn GH: Local seed systems and their importance for an improved seed supply in developing countries. Euphytica 1994, 78(3):207-216

17. Sperling $L$, Cooper HD, Remington T: Moving towards more effective seed aid J Dev Stud 2008, 44(4):586-612

18. DeVries J, Toenniessen G: Securing the harvest: biotechnology, breeding and seed systems for African crops. New York, USA: CABl; 2002

19. Langyintuo AS, Mwangi W, Diallo AO, MacRobert J, Dixon J, Banziger M: Challenges of the maize seed industry in eastern and southern Africa: a compelling case for private-public intervention to promote growth. Food Policy 2010, 35(4):323-331.

20. Lunduka R, Fisher M, Snapp S: Could farmer interest in a diversity of seed attributes explain adoption plateaus for modern maize varieties in Malawi? Food Policy 2012, 37(5):504-510.

21. Gibson R, Lyimo N, Temu A, Stathers T, Page W, Nsemwa L, Acola G, Lamboll R: Maize seed selection by East African smallholder farmers and resistance to maize streak virus*. Ann Appl Biol 2005, 147(2):153-159.

22. Mortimore M, Adams W: Farmer adaptation, change and 'crisis' in the Sahel. Glob Environ Change: Human Policy Dim 2001, 11(1):49-57.

23. Bellon MR, Adato M, Becerril J, Mindek D: Poor farmers' perceived benefits from different types of maize germplasm: the case of creolization in lowland tropical Mexico. World Dev 2006, 34(1):113-129.

24. Bellon M, Risopoulos J: Small-scale farmers expand the benefits of improved maize germplasm: a case study from Chiapas, Mexico. World Dev 2001, 29(5):799-811.

25. Louwaars NP, de Boef WS: Integrated seed sector development in Africa: a conceptual framework for creating coherence between practices, programs, and policies. J Crop Improve 2012, 26(1):39-59.

26. Scoones I, Thompson J: The politics of seed in Africa's green revolution: alternative narratives and competing pathways. IDS Bull 2011, 42(4):1-23.

27. McGuire S, Sperling L: Making seed systems more resilient to stress. Glob Environ Change: Human Policy Dim 2013, 23(3):644-653.

28. Sperling L, McGuire S: Fatal gaps in seed security strategy. Food Sec 2012, 4(4):1-11.

29. Smit B, Wandel J: Adaptation, adaptive capacity and vulnerability. Glob Environ Change: Human Policy Dim 2006, 16(3):282-292.

30. Vermeulen SJ, Challinor AJ, Thornton PK, Campbell BM, Eriyagama N, Vervoort JM Kinyangi J, Jarvis A, Läderach P, Ramirez-Villegas J: Addressing uncertainty in adaptation planning for agriculture. Proc Natl Acad Sci USA 2013, 110(21):8357-8362.

31. Parry ML, Canziani OF, Palutikof JP, van der Linden PJ, Hanson CE: Climate change 2007: impacts, adaptation and vulnerability. Contribution of working group II to the fourth assessment report of the Intergovernmental Panel on Climate Change (IPCC) Cambridge, UK: Cambridge University Press; 2007:976.

32. Adger WN, Agrawala S, Mirza MMQ, Conde C, O'Brien K, Pulhin J, Pulwarty R, Smit B, Takahashi K: Assessment of adaptation practices, options, constraints and capacity. In Climate change 2007: impacts, adaptation and vulnerability. Contribution of working group II to the fourth assessment report of the Intergovernmental Panel on Climate Change. Edited by Parry ML, Canziani OF, Palutikof JP, van der Linden PJ, Hanson CE. Cambridge, UK: Cambridge University Press; 2007:717-743.

33. Knox J, Hess T, Daccache A, Wheeler T: Climate change impacts on crop productivity in Africa and South Asia. Environ Res Lett 2012, 7(3):034032.
34. Parry ML, Rosenzweig C, Iglesias A, Livermore M, Fischer G: Effects of climate change on global food production under SRES emissions and socio-economic scenarios. Glob Environ Change: Human Policy Dim 2004, 14(1):53-67.

35. Adger WN, Huq S, Brown K, Conway D, Hulme M: Adaptation to climate change in the developing world. Prog Dev Stud 2003, 3(3):179-195.

36. O'Brien K, Leichenko R, Kelkar U, Venema H, Aandahl G, Tompkins H, Javed A, Bhadwal S, Barg S, Nygaard L, West J: Mapping vulnerability to multiple stressors: climate change and globalization in India. Glob Environ Change: Human Policy Dim 2004, 14(4):303-313.

37. Ministry of Agriculture, Food Security and Cooperatives: Ministry of agriculture, food security and cooperatives. [http://www.agriculture.go.tz/]

38. Haug $\mathrm{R}$, Hella J: The art of balancing food security: securing availability and affordability of food in Tanzania. Food Security 2013, 5:415-426.

39. FAOSTAT: [http://faostat3.fao.org/home/index.html]

40. Schlenker W, Lobell DB: Robust negative impacts of climate change on African agriculture. Environ Res Lett 2010, 5(1):014010.

41. Rowhani P, Lobell DB, Linderman M, Ramankutty N: Climate variability and crop production in Tanzania. Agr Forest Meteorol 2011, 151(4):449-460

42. Ritchie J, Singh U, Godwin D, Bowen W: Cereal growth, development and yield. Syst Appro Sustain Agri Dev 1998, 7:79-98.

43. Ellis F: Rural livelihoods and diversity in developing countries. Oxford, UK: Oxford University Press; 2000

44. Scoones I: Livelihoods perspectives and rural development. J Peasant Stud 2009, 36(1):171-196.

45. Bellon MR, Hellin J: Planting hybrids, keeping landraces: agricultural modernization and tradition among small-scale maize farmers in Chiapas, Mexico. World Dev 2011, 39(8):1434-1443.

46. Ellis F, Mdoe N: Livelihoods and rural poverty reduction in Tanzania. World Dev 2003, 31(8):1367-1384.

47. Paavola J: Livelihoods, vulnerability and adaptation to climate change in Morogoro, Tanzania. Environ Sci Pol 2008, 11(7):642-654

48. Fisher M, Chaudhury M, McCusker B: Do forests help rural households adapt to climate variability? Evidence from Southern Malawi. World Dev 2010 38(9):1241-1250.

49. Kristjanson P, Neufeldt H, Gassner A, Mango J, Kyazze FB, Desta S, Sayula G, Thiede B, Förch W, Thornton PK: Are food insecure smallholder households making changes in their farming practices? Evidence from East Africa. Food Security 2012, 4(3):381-397.

50. R Project: [http://www.r-project.org/]

51. Analysis of overdispersed data. [http//cran.r-project.org/web/packages/aod/index.html].

52. Mary A, Majule A: Impacts of climate change, variability and adaptation strategies on agriculture in semi arid areas of Tanzania: the case of Manyoni district in Singida region, Tanzania. Afr J Environ Sci Technol 2009, 3(8):206-218.

53. Slegers M: 'If only it would rain': Farmers' perceptions of rainfall and drought in semi-arid central Tanzania. J Arid Environ 2008, 72(11):2106-2123.

54. Morton JF: The impact of climate change on smallholder and subsistence agriculture. Proc Natl Acad Sci USA 2007, 104(50):19680-19685.

55. Mortimore M: Adapting to drought in the Sahel: lessons for climate change. Wiley Interdiscip Rev Clim Chang 2010, 1(1):134-143.

56. Vermeulen SJ, Campbell BM, Ingram JS: Climate change and food systems. Annu Rev Environ Resour 2012, 37(1):195-222

57. Eriksen SH, Brown K, Kelly PM: The dynamics of vulnerability: locating coping strategies in Kenya and Tanzania. Geogr J 2005, 171:287-305.

58. Liwenga ET: Adaptive livelihood strategies for coping with water scarcity in the drylands of central Tanzania. Phys Chem Earth 2008, 33(8):775-779.

59. Naess LO: The role of local knowledge in adaptation to climate change. Wiley Interdiscip Rev Clim Chang 2013, 4:99-106.

60. Goulden M, Naess LO, Vincent K, Adger WN: Accessing diversification, networks and traditional resource management as adaptations to climate extremes. In Adapting to climate change: thresholds, values, governance. Edited by Adger WN, Lorenzoni I, O'Brien K. Cambridge, UK: Cambridge University Press; 2009:514

61. Feder G, Just RE, Zilberman D: Adoption of agricultural innovations in developing countries: a survey. Econ Dev Cult Chang 1985, 33(2):255-298.

62. Erenstein O, Kassie GT, Langyintuo A, Mwangi W: Characterization of maize producing households in drought prone regions of Eastern Africa. Mexico: CIMMYT; 2011

63. Nordhagen S, Pascual U: The impact of climate shocks on seed purchase decisions in Malawi: implications for climate change adaptation. World Dev 2013, 43:238-251.

64. Chibwana C, Fisher M, Shively G: Cropland allocation effects of agricultural input subsidies in Malawi. World Dev 2012, 40(1):124-133. 
65. Westengen OT, Ring KH, Berg PR, Brysting AK: Modern maize varieties going local in the semi-arid zone in Tanzania. BMC Evol Biol 2014, 14(1):1.

66. Bänziger M: Breeding for drought and nitrogen stress tolerance in maize: from theory to practice. Mexico: CIMMYT; 2000.

67. Lobell DB, Bänziger M, Magorokosho C, Vivek B: Nonlinear heat effects on African maize as evidenced by historical yield trials. Nat Clim Chang 2011, 1(1):42-45.

68. CIMMYT: Choosing the right open-pollinated maize in Southern Africa. Mexico; 2010:3.

69. Bellon MR, Taylor JE: 'Folk' soil taxonomy and the partial adoption of new seed varieties. Econ Dev Cult Chang 1993, 41(4):763-786.

70. Bellon MR, Hodson D, Hellin J: Assessing the vulnerability of traditional maize seed systems in Mexico to climate change. Proc Natl Acad Sci USA 2011, 108(33):13432-13437.

doi:10.1186/2048-7010-3-3

Cite this article as: Westengen and Brysting: Crop adaptation to climate change in the semi-arid zone in Tanzania: the role of genetic resources and seed systems. Agriculture \& Food Security 2014 3:3.

\section{Submit your next manuscript to BioMed Central and take full advantage of:}

- Convenient online submission

- Thorough peer review

- No space constraints or color figure charges

- Immediate publication on acceptance

- Inclusion in PubMed, CAS, Scopus and Google Scholar

- Research which is freely available for redistribution 